\title{
CONTENTS VOLUME 6
}

Database teaching in the information storage and retrieval syllabus

Business information courses: a consideration of requirements

N. ROBERTS, T.D. WILSON and D. ELLIS

Reactions of past students to the Bachelor of Library Science degree of Ahmadu Bello University, Zaria, Nigeria

G.T. ONADIRAN

Demand and supply in information work

L. DAVENPORT and B. CRONIN

The use of INFO, a database management system, in teaching Library and Information Studies at Manchester Polytechnic (Software Section)

J.E. ROWLEY, J.F. FARROW A J. OULTON and A.J. WOOD

Book Reviews

Research and education for research in Nigerian library schools

Teaching conservation

J.R. TURNER

The imperative for change: Curriculum revision in South Africa

M. NASSIMBENI

Library and information science education in Norway

T. ALNAES

Library and information science education in the Netherlands: The undergraduate programme (Short Communication)

C. FARROW 
Data display panel: The Efl DD-1000 (Short Communication)

G. MARTIN

USM/IDRC regional training course on library automation, The CDS/ISIS training course on library automation (Reports on Training Courses)

E. LIM H.T.

Book Reviews

News

Translations of Abstracts

Calendar of Events

Editorial

Education and training for librarianship and information work: Annual bibliography, 1987

A.J. CLARK

Online education and marketing: $A$ joint approach

J.M. DAY and K. O'DONOVAN

Reference and information work in local history: Training for librarians

D. PAUL

Letter to the editor

Book Reviews

Book Notices

Translations of Abstracts

The educational framework for information professionals in Spain: A proposal and some suggestions

A. MASSISIMO and M.C. MAYOL

The MLIS programme at the Institute for Advanced Studies, University of Malaya

S.M. KHOO

CD-ROM - An online training tool?

J.M. DAY

Teaching bibliometric analysis and MS/DOS commands

H. DOU, L. QUONIAM and P. HASSANALY 
The applied social science modular scheme: BSc in information and communication studies: 1988

K. MCGARRY

Book Reviews

Book Notices

Translations of Abstracts 